\title{
INFORMATION TECHNOLOGY AND BUSINESS PROCESS OUTSOURCING TO INDIA: IMPLICATIONS AND CHALLENGES
}

\author{
Kamal Hingorani, Alabama State University, khingorani@alasu.edu
}

\begin{abstract}
India has emerged as the 'nerve-centre' for Information Technology - Business Process Outsourcing (IT-BPO) with over two-third of the Fortune 500 and a majority of the Global 2000 firms now sourcing global service delivery from India [32]. The top four Indian IT-BPO companies have attained global stature and now have a combined market capitalization of $\$ 72.67$ billion, which dwarfs many of their US-based competitors.
\end{abstract}

The purpose of this paper is to analyze the competitive advantage that Indian IT-BPO companies have over similar U.S. companies. Extensive research was conducted using both public disclosers provided by these companies to the Securities and Exchange Commission and the public data available on the Internet.

The challenges faced by the Indian companies have been enumerated and implications for US based companies and our educational system are discussed.

Keywords: Information Technology (IT), Content Analysis, Outsourcing, Business Process Outsourcing, India

\section{INTRODUCTION}

The dramatic increase in the number of companies outsourcing their Information Technology and Business Processes (IT-BPO) to foreign shores over the last several years is an area of growing concern to many Americans [11, 12, and 17]. The main advantage of offshore outsourcing is cost cutting and savings, but it is difficult to get an objective view of this topic because many reports and articles have a vested interest in their position that is effected by economic or political concerns [4, 6, 8, 9, 11, 12, 14, and 19]. Many of us can personally still recall $H$. Ross Perot, in his bid for the Presidency during 1992, claiming NAFTA would create "a giant sucking sound to the south" such that no jobs would remain in the US. Dire predictions have been around as long as the movement of jobs has existed.
India has emerged as the 'nerve-centre' for Information Technology - Business Process Outsourcing (IT-BPO). Four of India's IT-BPO companies - Infosys Technologies (INFY), Tata Consultancy Services (TCS), Wipro (WIT) and Satyam Computers Services (SAY) - are among the 35 largest companies in India. These four companies together had a market capitalization of $\$ 72.67$ billion (as of April 30, 2008), employed 335,483 professional (as of March 31, 2008) and had combined revenues of $\$ 16.94$ billion during 20072008. Their revenues grew by a staggering $34 \%$ over a year [23, 24, 35, 36, 47, and 48]. The four companies increased their head count by 66,941 employees during 2007-2008.

This paper raises an important issue: will the IT-BPO industry, which is dominated by US-based companies like IBM, Electronic Data System (EDS), Accenture (ACN), Computer Sciences (CSC), suffer the same fate that the US automotive industry is going through at this time, or will the government, universities, and industry wake up to the challenges?

The proposed acquisition of EDS by Hewlett-Packard will help the combined company gain the economies of scale that is necessary to effectively compete in the global marketplace. It is also gratifying that the some of the state governments have introduced legislation that creates a barrier to IT-BPO. The federal government, on the other hand, is trying to make outsourcing easier; they have tried many times to raise the caps on the H1-B visas. However, wiser counsels have prevailed. The recent enrollment trends in computer sciences and management information systems majors indicate that much damage has already occurred; the educational and governmental authorities have to wake up and take immediate corrective actions so that our nation remains competitive in the global marketplace.

\section{LITERATURE REVIEW}

The offshore outsourcing industry is now estimated to be around thirty-five years old. During the 1970s, most offshoring activity was to Israel [40]. In the 1990s, as more countries began opening up their doors to international trade and to the exchange of 
jobs and services, the trend towards outsourcing began to increase dramatically. Currently, the important players in this market are India, China, the Philippines, Russia and South Africa. India is the country receiving the most press and having the greatest impact on offshoring of services. With more than one billion people and a large educated Englishspeaking work force, India has become a major player in offshoring, especially of IT-BP services. Low cost computer programmers from India were used extensively in the Y2K crisis and during the dotcom boom. The trend has grown ever since then [9, $15,16,18$, and 19].

It is generally agreed that the main factors influencing the beginnings of the offshore outsourcing movement were a combination of pressures to reduce labor costs and improve productivity and an expanding, economical labor pool in other countries [33]. It is estimated that by offshoring software and IT services including callcenters, U.S. companies can achieve a twenty to twenty-five percent gain in productivity [3]. Another benefit often suggested is that companies can increase or decrease their work forces quickly to reflect peaks and valleys in production or demand, as well as reduce their investment in equipment or infrastructure [2]. Cost savings are said to create value in the U.S. economy, and it is sometimes claimed that offshore outsourcing makes U.S. companies more globally competitive.

A recent study conducted by IBM [21], which used a patented methodology to understand the long-term impact of IT outsourcing on earnings before interest and taxes (EBIT), selling, general and administrative (SG\&A) expenses, and return on assets (ROA), found that companies that engaged in IT outsourcing contracts valued at US\$50 million or more realized long-term improvements as compared to sector peers. Companies in the study experienced an annual growth in earnings that was 11.8 points higher than the sector median. Their selling, general and administrative expenses were nearly 9.9 points lower than the sector median while the return on assets annual growth was 8.6 points higher than the sector median - a swing of 16.1 points. Prior to outsourcing, the companies' ROA growth rate was 7.5 points lower than the sector median.

Koch [26] has enumerated a number of drawbacks of outsourcing and has warned that outsourcing of manufacturing, IT-BPO, and engineering design may, in the long term, reduce innovation and competitiveness among U.S. companies.
The orthodox view that the American economy will benefit in the long run from all forms of international trade, including IT-BPO, is shared by many economic czars such as Alan Greenspan, former chairman of the Federal Reserve, N. Gregory Mankow, former chairman of the White House Council of Economic Advisers, and Jagdish N. Bhagwati, a leading international economist and professor at Columbia University [6, 29]. The mainstream economists acknowledge that some people will gain and others will suffer in the short term, but they quickly add that "the gains of the American winners are big enough to more than compensate for the losers." One prominent economist who disagrees with this view is the Nobel laureate- Mr. Samuelson. He believes that this assumption, so widely shared by economists, is only an innuendo and is dead wrong about necessary surplus of winnings over losings. In other words, trade may not always work to the advantage of the American economy according to Mr. Samuelson [34].

\section{SIZE AND SCOPE OF INDIA'S IT-BPO INDUSTRY}

The overall Indian IT-BPO revenue aggregate is expected to grow by over thirty-three percent and reach 64 billion dollars during 2007-2008 [31, 32]. Over the same period, direct employment in the sector is expected to reach nearly two million, an increase of about 375,000 professionals over the previous year [32]. As a proportion of national GDP, the Indian technology sector revenues have grown from 1.2 per cent in FY1998 to an estimated 5.5 per cent in FY2008 [32]. NASSCOM [34] also projects that the revenues of IT-BPO will rise to $\$ 75$ billion by 2010 .

IT companies form the backbone of the Bombay Stock Exchange in India. Four IT-BPO companies are ranked at number 9, 13, 19 and 34 in terms of market capitalization as of market closing on April 30, 2008. These four companies had a gross market capitalization of \$ 72.67 billion (as of April 30, 2008), as shown in Table 1.

Market capitalization is a measure of corporate or economic size equal to the share price times the number of shares outstanding of a public company. The market capitalization of all 1924 companies traded on the NYSE was $\$ 18.97$ trillion as on May 9, 2008. 
Table 1: Market Capitalization of Select Indian IT-BPO Companies (as of April 30, 2008)

\begin{tabular}{|c|c|c|}
\hline Rank & Company Symbol & $\begin{array}{l}\text { Market Cap } \\
\text { Billion \$ }\end{array}$ \\
\hline $\mathbf{9}$ & INFY & 24.79 \\
\hline $\mathbf{1 3}$ & TCS & 22.24 \\
\hline $\mathbf{1 9}$ & WIT & 17.65 \\
\hline $\mathbf{3 4}$ & SAY & 7.99 \\
\hline & Total & $\mathbf{7 2 . 6 7}$ \\
\hline
\end{tabular}

Infosys Technologies (INFY), Wipro (WIT), and Satyam Computer Services (SAY) have American Depositories Receipts (ADRs) that are very actively traded on the NYSE/NASDAQ stock exchanges. An ADR is a negotiable certificate issued by a U.S. bank representing a specified number of shares in a foreign stock that is traded on a U.S. exchange. ADRs are denominated in U.S. dollars, with the underlying security held by a U.S. financial institution overseas.

The prices of the ADRs as on April 30, 2008 and the market capitalization of the companies are shown in Table 2. The ADRs of these and other Indian companies are generally quoted at a premium over the prices of the underlying security in India which explains some of the difference in their market capitalization when compared to the figures in Table 1. Indian law imposes foreign investment restrictions that limit a holder's ability to convert equity shares into ADRs, which may explain why ADRs trade at a premium to the market price of the equity shares in India.

Table 2- Market Capitalization of Select Indian IT-BPO Companies Traded In US

\begin{tabular}{|l|r|r|}
\hline Company Symbol & \multicolumn{1}{|l|}{$\begin{array}{l}\text { ADRs } \\
\mathbf{0 4 / 3 0 / 2 0 0 8}\end{array}$} & $\begin{array}{l}\text { Market Cap } \\
\text { Billion \$ }\end{array}$ \\
\hline INFY & $\$ 43.69$ & 24.99 \\
\hline WIT & $\$ 13.00$ & 18.99 \\
\hline SAY & $\$ 25.68$ & 8.61 \\
\hline
\end{tabular}

The data presented above details the size of the Indian IT-BPO companies many of which were incorporated in the early 1990s. These companies have grown to a size that is larger than many of their U.S. competitors. The market capitalizations of their important US competitors are shown in Table 3. No separate data is available for IBM-Global Servicesthe IT-BPO unit of the larger IBM Corporation.
Table 3- Market Capitalization of Select U.S. Competitors

\begin{tabular}{|l|c|c|}
\hline & $\begin{array}{l}\text { Stock } \\
\text { Price } \\
\mathbf{0 4 / 3 0 / 2 0 0 8}\end{array}$ & $\begin{array}{l}\text { Market } \\
\text { Cap } \\
\text { Billion \$ }\end{array}$ \\
\hline Accenture (ACN) & $\$ 37.55$ & 22.33 \\
\hline $\begin{array}{l}\text { Electronic Data } \\
\text { Systems (EDS) }\end{array}$ & $\$ 18.56$ & 9.48 \\
\hline $\begin{array}{l}\text { Computer Sciences } \\
\text { (CSC) }\end{array}$ & $\$ 44.33$ & 6.91 \\
\hline
\end{tabular}

\section{THE INDIAN ADVANTAGE}

India is recognized as the premier destination for ITBPO services. According to India's NASSCOM (National Association of Software and Services Companies), revenues from IT-BPO services are expected to cross $\$ 75$ billion by the year 2010 period. There are several key factors contributing to success of India's IT-BPO industry.

\section{High Quality Delivery.}

Indian companies have developed a reputation for high quality delivery. According to the Process Maturity Profile, published by the Carnegie Mellon Software Engineering Institute, in March 2008, 323 Indian companies had acquired quality certifications with approximately 151 companies certified at SEICMM Level 5 - more than any other country in the world [37]. SEI-CMM is the Carnegie Mellon Software Engineering Institute's Capability Maturity Model, which assesses the quality of organizations' management system processes and methodologies. Level 5 is the highest level of the CMM assessment. All the four Indian companies studied in this research have achieved the Level 5 certification.

\section{Significant Cost Benefits.}

India has a strong track record of delivering a significant cost advantage, with clients reporting savings of up to 25-50 percent over the original cost base [32, 31, and 32]. This is also recognized by one of their US based competitors-Accenture. In their latest $10-\mathrm{K}$ statement, the company had the following statement: "We compete with Off-shore service providers in lower-cost locations, particularly Indian providers, that offer services similar to those we offer, often at highly competitive prices” [1].

\section{Abundant Skilled Resources.}

India has a large and highly skilled English-speaking labor pool. India produces approximately 3.1 million university and college graduates, including approximately 500,000 technical graduates, annually $[30,32]$. 


\section{RESEARCH METHOD}

This study investigated the competitive advantage of the Indian IT-BPO companies using content analysis. Content analysis is an observational research method used to systematically evaluate the content of recorded communications [25]. Content analysis has been defined as a systematic, replicable technique for compressing many words of text into fewer content categories based on explicit rules of coding [6, 27, 43, and 46]. Holsti [20] offers a broad definition of content analysis as, "any technique for making inferences by objectively and systematically identifying specified characteristics of messages" [p. 14]. Content analysis extends far beyond simple word counts. The technique can be made particularly rich and meaningful by coding and the categorizing of the data [46].

20-F statements as filed with the Securities and Exchange Commission, of three Indian IT-BPO companies for 2005-2006, 2006-2007, and 20072008 were used for the content analysis. A foreign issuer of equity has to file an annual report to the SEC on a 20-F form. This is a statutory requirement under Section 13(a) or 15(d) of the SEC Act. The annual report must be filed within six months after the end of the fiscal year. The 20-F statement of INFY for 2007-2008 was also examined. WIT and SAY had not yet filed their 20-F for 2007-2008 at the time of writing of this paper. They had, however, released their financial statements for the year, which have been incorporated in this research.

The 20-F statement has a section on risk factors. This section was used for the content analysis. The size of these documents for the year 2006-2007 for the three companies is shown in Table 4.

Table 4- Word Count of Documents Used For Content Analysis

\begin{tabular}{|l|c|}
\hline Company & Word Count \\
\hline INFY & 12,556 \\
\hline SAY & 11,666 \\
\hline WIT & 8,747 \\
\hline
\end{tabular}

The 20-F statements were read and re-read in order to code for emergent themes. In using qualitative techniques such as content analysis, it is important that the person analyzing the data allows themes to emerge naturally, rather than attempting to impose a preconceived set of themes on the data [38]. Since this was an exploratory study, content analysis, after meaningful categorization of data, was used to observe trends. No detailed statistical analysis was performed with the exception of simple frequency analysis.

\section{DATA ANALYSIS}

The use of the database management system Microsoft Access is widespread in the MIS community. This software allows for various ways of entering, managing, importing, and exporting data. The text data can be conveniently handled due to the availability of memo data field.

The risk factors from the 20-F statements were converted into a text file. The spaces between words were automatically replaced by manual line break using Microsoft Word. The resulting text file was imported as a table into a Microsoft Access database. The database table had two fields, one was a key (auto number), and the other was the words used in the document. The content analysis was conducted using simple select queries in Access using grouping and aggregate functions. The results of the content analysis (data for year 2007-2008) are shown in Table 5. The content-analysis relied on word frequency.

Table 5- Frequency of Words (Contents)

\begin{tabular}{|l|r|r|r|}
\hline & \multicolumn{1}{|l|}{ INFY } & \multicolumn{1}{l|}{ SAY } & \multicolumn{1}{l|}{ WIT } \\
\hline Taxes & 44 & 27 & 24 \\
\hline Visa & 32 & 17 & 21 \\
\hline Clients & 99 & 1 & 86 \\
\hline Customers & 10 & 95 & 8 \\
\hline Employees & 48 & 21 & 35 \\
\hline Competition & 39 & 29 & 26 \\
\hline US & 106 & 28 & 43 \\
\hline ADR & 50 & 59 & 32 \\
\hline Currency & 22 & 13 & 11 \\
\hline Europe & 12 & 4 & 4 \\
\hline Dollar & 18 & 17 & 0 \\
\hline Euro & 7 & 0 & 0 \\
\hline
\end{tabular}

There appeared little difference between the three companies except that SIFY used the word customer instead of the word client. As stated earlier, the focus of the analysis was on understanding the companies' views about their competitive advantages through the section on risk factors in their 20-F statements. The presence or frequencies of certain aspects of content were used to observe trends that were then used in 
the results to determine some aspects of the competitive advantages of the Indian companies.

The findings are discussed in the next section. Table6 details the revenues, taxes, and percentage contribution of large clients of the four Indian ITBPO companies. This table has been extensively referred to in the section on findings.

Table 6: Select Data for Indian Companies

\begin{tabular}{|c|c|c|c|c|}
\hline & \multicolumn{4}{|c|}{ Figures in \$ Millions } \\
\hline & $\begin{array}{l}2004- \\
2005\end{array}$ & $\begin{array}{l}2005- \\
2006\end{array}$ & $\begin{array}{l}2006- \\
2007\end{array}$ & $\begin{array}{l}2007- \\
2008\end{array}$ \\
\hline \multicolumn{5}{|l|}{ WIT } \\
\hline Revenues & $\$ 1,863$ & $\$ 2,387$ & $\$ 3,436$ & $\$ 4,933$ \\
\hline Taxes & $\$ 61$ & $\$ 73$ & $\$ 85$ & $\$ 97$ \\
\hline Net Income & $\$ 426$ & $\$ 529$ & $\$ 755$ & $\$ 806$ \\
\hline Top Client & $4.0 \%$ & $3.0 \%$ & $3.0 \%$ & NA \\
\hline $\begin{array}{l}10 \text { Largest } \\
\text { Clients }\end{array}$ & $27.0 \%$ & $27.0 \%$ & $25.0 \%$ & NA \\
\hline \multicolumn{5}{|l|}{ SAY } \\
\hline Revenues & $\$ 794$ & $\$ 1,096$ & $\$ 1,461$ & $\$ 2,138$ \\
\hline Taxes & $\$ 25$ & $\$ 38$ & $\$ 31$ & $\$ 53$ \\
\hline Net Income & $\$ 155$ & $\$ 250$ & $\$ 298$ & $\$ 417$ \\
\hline Top Client & $10.8 \%$ & $8.8 \%$ & $6.3 \%$ & NA \\
\hline $\begin{array}{l}\text { 2nd Largest } \\
\text { Client }\end{array}$ & $7.4 \%$ & $5.1 \%$ & $4.4 \%$ & NA \\
\hline $\begin{array}{l}5 \text { Largest } \\
\text { Clients }\end{array}$ & $29.2 \%$ & $24.2 \%$ & $21.0 \%$ & NA \\
\hline \multicolumn{5}{|l|}{ INFY } \\
\hline Revenues & $\$ 1,592$ & $\$ 2,152$ & $\$ 3,090$ & $\$ 4,176$ \\
\hline Taxes & $\$ 72$ & $\$ 70$ & $\$ 84$ & $\$ 171$ \\
\hline Net Income & $\$ 419$ & $\$ 555$ & $\$ 850$ & $\$ 1,155$ \\
\hline Top Client & $6 \%$ & $4 \%$ & $7 \%$ & $9 \%$ \\
\hline $\begin{array}{l}5 \text { Largest } \\
\text { Client }\end{array}$ & $19 \%$ & $18 \%$ & $19 \%$ & $21 \%$ \\
\hline \multicolumn{5}{|l|}{ TCS } \\
\hline Revenues & NA & NA & $\$ 4,650$ & $\$ 5,700$ \\
\hline Taxes & NA & NA & $\$ 166$ & $\$ 186$ \\
\hline Net Income & NA & NA & $\$ 1,026$ & $\$ 1,252$ \\
\hline Top Client & NA & NA & $6.6 \%$ & $6.5 \%$ \\
\hline $\begin{array}{l}5 \text { Largest } \\
\text { Clients }\end{array}$ & NA & NA & $18.5 \%$ & $18.9 \%$ \\
\hline $\begin{array}{l}10 \text { Largest } \\
\text { Clients }\end{array}$ & NA & NA & $28.4 \%$ & $29.1 \%$ \\
\hline \multicolumn{3}{|c|}{ Total Revenues } & $\$ 12,637$ & $\$ 16,947$ \\
\hline
\end{tabular}

The data for TCS is limited to two years because the company is not listed in the US and does not file with the SEC. The 20-F statements for the year 2007-2008 had not been filed by SAY and WIT at the time of writing of this paper.

\section{FINDINGS/DISCUSSION}

This study found, as expected, significant trends which are discussed below.

\section{F1- A Very Small Number Of US Clients Are Responsible For The Success Of Indian IT-BPO Companies.}

During 2007-2008, INFY's largest client accounted for approximately $9.1 \%$ of their total revenues. In dollar amount, one US client paid INFY \$380 million during one single year for IT-BPO services. For TCS, the largest client account accounted $6.5 \%$ of their revenues, that client contributed $\$ 371$ millions during 2007-2008. For WIT, these figures were $3 \%$ and $\$ 148$ million while for SAY these figures were 6.3\% and \$134 million. In summary, four US clients together bought IT-BPO services worth $\$ 1.03$ billion from India in one single year. The contribution from the top 5 and top 10 clients for these companies range from $20-30 \%$ of these companies' revenues. All these companies report in their $20-\mathrm{F}$ statements that they are trying to diversify their customer base and be less susceptible to major disruptions due to a loss of a major client.

The breakdown of revenues by sector as reported by INFY in their 20-F is shown in Table 7, suggesting that their largest client belongs to the financial services sector.

Table 7- Revenues by Sector (INFY)

\begin{tabular}{|l|r|r|r|}
\hline & \multicolumn{3}{|c|}{ Fiscal } \\
\hline & $\mathbf{2 0 0 6}$ & $\mathbf{2 0 0 7}$ & $\mathbf{2 0 0 8}$ \\
\hline Financial Services & $36.0 \%$ & $37.4 \%$ & $35.8 \%$ \\
\hline Manufacturing & $13.9 \%$ & $13.5 \%$ & $14.7 \%$ \\
\hline Telecommunications & $16.4 \%$ & $19.3 \%$ & $21.6 \%$ \\
\hline Retail & $10.2 \%$ & $10.1 \%$ & $11.8 \%$ \\
\hline $\begin{array}{l}\text { Others (utilities, } \\
\text { logistics \& services) }\end{array}$ & $23.5 \%$ & $19.7 \%$ & $16.1 \%$ \\
\hline Total & $100 \%$ & $100 \%$ & $100 \%$ \\
\hline
\end{tabular}

The figures for the other three companies are also in the same range.

\section{F2-United States Continues To Be Their Biggest Market.}

The geographical distribution of revenues for these four companies for the year 2007-2008 is shown in Table 8. 
Table 8- Revenues by Geographical Region (2007-2008)

\begin{tabular}{|l|r|r|r|r|}
\hline & INFY & TCS & WIT & SAY \\
\hline $\begin{array}{l}\text { North } \\
\text { America }\end{array}$ & $62.0 \%$ & $55.1 \%$ & $44 \%$ & $60.2 \%$ \\
\hline Europe & $28.1 \%$ & $29 \%$ & $27 \%$ & $20.6 \%$ \\
\hline India & $1.3 \%$ & $9 \%$ & $22 \%$ & - \\
\hline $\begin{array}{l}\text { Rest of } \\
\text { World }\end{array}$ & $8.6 \%$ & $6.9 \%$ & $7 \%$ & $19.2 \%$ \\
\hline Total & $100 \%$ & $100 \%$ & $100 \%$ & $100 \%$ \\
\hline
\end{tabular}

Of the total revenues of $\$ 16.94$ billion reported by these four companies, $\$ 9.18$ billion were from US based clients.

The US Census Bureau reports the monthly trade statistics for all our trading partners. The trend of USIndia trade as per the figures of the Census Bureau is shown in Table 9 [42].

Table 9- U.S.-India Trade (\$ Billion)

\begin{tabular}{|l|r|r|r|r|}
\hline & 2004 & 2005 & 2006 & 2007 \\
\hline Imports & 15.57 & 18.80 & 21.83 & 24.02 \\
\hline Exports & 6.10 & 7.98 & 10.05 & 17.59 \\
\hline Imbalance & -9.46 & -10.81 & -11.77 & -6.43 \\
\hline
\end{tabular}

U.S. runs a trade deficit with India. The figures in Table-9 do not include IT-BPO services. The U.S. government is therefore underreporting the trade imbalance with India. Given the importance of this category of data in understanding the extent of offshoring of services, a subject of continuing public and congressional concern, additional efforts to strengthen the quality of U.S. services data are merited. The U.S. GAO has acknowledged this fact in a report to the U.S. Congress [44].

\section{F3-A Weak Currency Is A Major Competitive Advantage.}

The functional currency of all these companies is the Indian rupee although they transact a major portion of their business in U.S. dollars. Accordingly, changes in exchange rates impacts revenues, other incomes, cost of services sold, gross margin, and net income.

The exchange rate between the Indian rupee and the U.S. dollar has changed substantially in recent years. Figure 1 shows the exchange rate of the Indian rupee (INR) and the US dollar during the last five years.

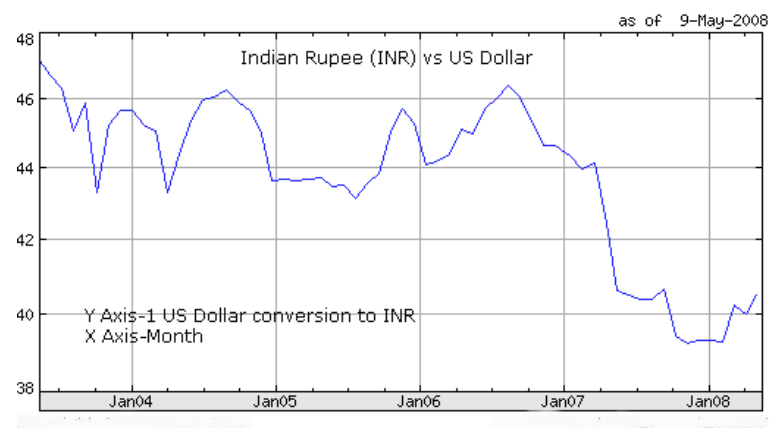

Figure 1 U.S. Dollar to Indian Rupee Exchange Rate

These companies were adversely affected during 2007-2008 when the rupee appreciated substantially against the U.S. dollar. To protect against an appreciating rupee, all the companies entered into forward and options contracts on currency. These companies have to follow the policies of the Reserve Bank of India, which limits the ability to hedge their foreign currency exposures adequately.

The financial performance of these companies showed considerable improvements in 2007-2008 despite the appreciating rupee. The Indian Rupee has started weakening since March 2008, which will help these companies in the future.

\section{F4-H1-B And L1 Visas Are Their Life Lines.}

Most of the IT-BPO projects require a portion of the work to be completed at the customer's location, which is typically outside India. The ability of Indians employees to work in the United States, Europe and in other countries outside India depends on the ability to obtain the necessary visas and work permits. In the United States a foreign national needs either a $\mathrm{H}-1 \mathrm{~B}$ visa, allowing the employee to remain in the United States during the term of the work permit and work as long as he or she remains an employee of the sponsoring firm, or a L-1 visa, allowing the employee to stay in the United States only temporarily. Although there is no limit to new L-1 visas, there is a limit to the aggregate number of new $\mathrm{H}-1 \mathrm{~B}$ visas that the U.S. Citizenship and Immigration Services (USCIS) may approve in any government fiscal year. The current limit of $\mathrm{H}-1 \mathrm{~B}$ visas is 65,000 . The USCIS has also issued new guidelines to more closely verify the qualifying criteria to restrict the liberal usage of L1visas.

During 2007, on April 10th, the first day that it started accepting applications, the USCIS received 150,000 H1-B visa applications for the year starting 
in October. The list of the companies requesting $\mathrm{H}$ $1 \mathrm{~B}$ visas in fiscal 2006 was dominated by Indianbased IT-BPO companies such as INFY, WIT, TCS, and SAY [19]. The H1-B visas requested by these companies are shown in Table 10.

Table 10- Application for H1-B Visas

\begin{tabular}{|l|l|}
\hline Company & H1-B Visa Requested \\
\hline INFY & 22,590 \\
\hline WIT & 19,450 \\
\hline TCS & 7,528 \\
\hline SAY & 7,235 \\
\hline Total & 56,803 \\
\hline
\end{tabular}

F5-Subsidies Provided By the Government of India Are a Competitive Advantage

A number of tax incentives under Indian tax laws are being provided to these Indian companies. These tax incentives currently include a tax holiday from payment of Indian corporate income taxes for Global IT Services and Products business operated from specially designated "Software Technology Parks" and "Special Economic Zones" in India and an income tax deduction of $100 \%$ for profits derived from exporting information technology services [38] These companies can also apply the tax paid in countries other than India as a credit against the Indian tax liability. These companies are also eligible for exemptions from other taxes, including customs duties. During 2007-2008, the combined taxes paid by these four companies were $\$ 507$ million. Their combined net income (after taxes) was \$3,630 million. During the six month period ending February 29, 2008, one U.S. company Accenture paid \$383 million in income taxes [1].

These tax incentives make the playing field uneven; the US-based companies have realized this and have jump started their Indian operations. The establishments of offshore facilities by the US multinationals will further reduce the availability of computer-related jobs in the US.

\section{F6-Political Climate In The US Can Affect Their Businesses.}

Recently, some countries and organizations have expressed concerns about a perceived association between offshore outsourcing and the loss of jobs. In the United States in particular, there has been increasing political and media attention on these issues following the growth of offshore outsourcing. Any changes in existing laws or the enactment of new legislation restricting offshore outsourcing may adversely impact their ability to do business in the United States, which is the largest market.

In the past, some U.S. states have proposed legislation restricting government agencies from outsourcing their back office processes, and IT solutions work to companies outside the United States or have enacted laws that limit or to discourage such outsourcing. The state government IT market is estimated to be about $\$ 50$ billion a year [9].

\section{F7-Wage Pressures Can Impact Business}

Wage costs in India, including in the IT services industry, have historically been significantly lower than wage costs in the United States and Europe for comparably skilled professionals. This is one of the most important competitive advantages of the Indian companies. Large companies, such as IBM, GE, Dell, $\mathrm{HP}$, EDS, CSC and Accenture, are establishing offshore operations in India, resulting in wage pressures for Indian companies.

Wages in India are increasing at a faster rate than in the United States, and this may result in increased cost of IT professionals. Wages in India are rising ten to fifteen percent a year but are still only a fifth of those paid to Western counterparts [32].

The four companies have a very high churn rates among their personnel and continue to hire at a very high rate. Call center attrition in India is 60 to $90 \%$, but that attrition for software engineers is much better. It is around fifteen percent that was common in Silicon Valley in the 1990s boom.

Table 11 shows the number of employees and the employees added during 2007-2008 by these four companies.

Table 11- Employees

\begin{tabular}{|l|r|r|}
\hline Company & $\begin{array}{l}\text { Employees } \\
\text { March 31, } \\
\text { 2008 }\end{array}$ & $\begin{array}{l}\text { Net Employees } \\
\text { Added during } \\
\text { 2007-2008 }\end{array}$ \\
\hline Infosys & 91,187 & 18,946 \\
\hline Wipro & 82,122 & 14,304 \\
\hline Satyam & 51,127 & 11,575 \\
\hline TCS & 111,407 & 22,116 \\
\hline Total & $\mathbf{3 3 5 , 8 4 3}$ & $\mathbf{6 6 , 9 4 1}$ \\
\hline
\end{tabular}

The four companies in aggregate employ 335,843 professional and increased their head count by 66,941 employees during 2007-2008. That is an amazing growth of $24.9 \%$ in one single year. India uses a mathematical unit called lacs which is 100,000 . Three of the companies either have or are very close to 
having one lac employees, which is a major milestone for Indian companies.

\section{F8-Increased Competition from US-Based Companies Setting Up Operations in India}

These Indian companies' primary direct US-based competitors include IBM-Global Services, Electronic Data System (EDS), Accenture (ACN), and Computer Sciences (CSC). IBM-Global Services is a part of the larger IBM Corporation and cannot be analyzed separately. The key financial comparative data for the competition is shown in the Table 12 below.

Table 12- COMPARISON OF DIRECT COMPETITORS

\begin{tabular}{|l|r|r|r|r|r|r|}
\hline & CSC & ACN & EDS & SAY & WIT & INFY \\
\hline Market Cap (\$B) & 7.05 & 22.1 & 9.83 & 8.70 & 24.6 & 18.9 \\
\hline Employees (000s) & 79 & 170 & 139 & 51 & 91 & 82 \\
\hline Revenues (\$ B) & 16.0 & 23.3 & 22.3 & 2.13 & 4.18 & 4.93 \\
\hline Rev/Emp (\$M) & 0.20 & 0.14 & 0.16 & 0.04 & 0.04 & 0.06 \\
\hline Rev. Growth (\%) & 14.3 & 17.2 & 2.70 & 35.8 & 32.3 & 29.1 \\
\hline Net Income (\$B) & .61 & 1.45 & .627 & .417 & 1.15 & .806 \\
\hline EPS (\$) & 3.53 & 2.27 & 1.17 & 1.19 & 2.02 & 0.53 \\
\hline P/E & 12.5 & 16.4 & 16.6 & 21.8 & 21.3 & 24.5 \\
\hline PEG & 1.36 & 1.05 & 1.16 & 0.9 & 0.81 & 1.04 \\
\hline P/S & 0.43 & 0.96 & 0.43 & 4.29 & 5.88 & 3.98 \\
\hline
\end{tabular}

Although the US companies are much larger in terms of employees and revenues, they trail the Indian competition in terms of Net Income, Earnings per Share, Price to Earning, Price/Earnings to Growth, and Price to Sales, all important financial parameters.

The revenues per employee for US companies are five times larger than those of their Indian counterpart. CSC generates revenues of $\$ 200,000$ per employee. In contrast, SAY generates only $\$ 40,000$ per employee. SAY is also more profitable than CSC.

The US companies have established operations in India and have mentioned India quite prominently in their 10K/10Q statements [1, 10, and 13].

\section{F8-The Indian IT-BPO Companies Have Started Branding Themselves.}

All the four BPO-IT companies started as small outfits in the early 1990s to do some back-office work for US companies. Over the last 15 years, these companies have grown rapidly and have become giants in their industry. These companies have now started branding and all the four companies have distinct corporate slogans that they prominently use on their websites. These slogans are shown in Table 13.

Table 13- Corporate Slogans

\begin{tabular}{|l|l|}
\hline Company & Corporate Slogan \\
\hline INFY & Win in a Flat World \\
\hline WIT & Applied Innovation \\
\hline SAY & Leadership through Innovation \\
\hline TCS & Innovation Drives Everything We Do \\
\hline
\end{tabular}

These companies have a huge and talented employee base and generate a lot of free cash. These companies will very soon compete in areas that many of us feel are protected such as development of software packages, etc.

\section{SUMMARY AND CONCLUSIONS}

India, after the massive increase in IT expenditures due to the Y2K problem, has become a giant in the IT-BPO industry. Their four top IT-BPO companies sport a market capitalization of $\$ 72.67$ billions. Over $60 \%$ of the revenues of these companies are from US companies. These four companies have a headcount of 335,843; they increased their headcount by 66,941 employees in one year. Most of the recruitment in these companies happens in college campuses. In contrast, there are very few job opening for new IS graduates in the US. This is impacting the enrollment in IS/MIS programs across the nation. This impact is best reflected in the enrollment data at the College of Business Administration of the University of Alabama [45]. Their MIS program, today, has only 52 students, against the 132 students it had in 1999 as shown in Figure 2.

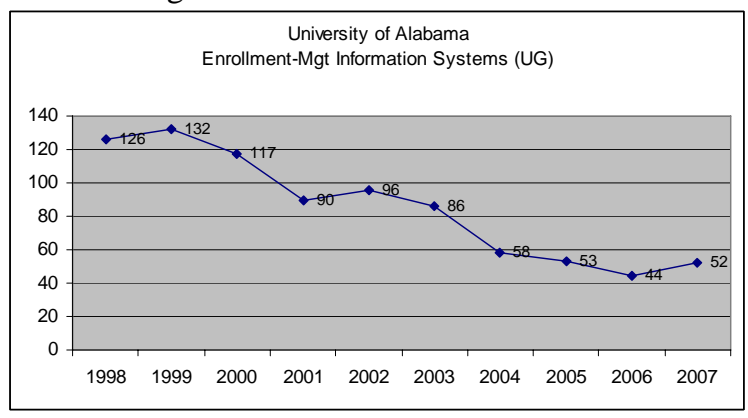

Figure 2: University of Alabama-MIS Enrollment

A recent public statement by the CEO of AT\&T suggested that the company is finding it difficult to recruit employees for the 5000 service jobs that they had promised to bring back to the US from India. This should be a rude awakening for policy makers in the US [41]. 
The US needs to be careful here. The automotive industry went through this process starting in the early 1980s. The results are right in our backyard with international companies setting up operations in the US and companies such as Hyundai, Honda, Mercedes-Benz and Toyota thriving at the expense of Ford, General Motors, and Chrysler. Toyota sells the second largest number of automobiles in the US and is on track to replace GM to become the world's top manufacturer in the very near future. Do we want TCS, INFY, WIT and SAY to be the next Toyota, Honda, Mercedes-Benz and Hyundai?

US companies need to take a long-term view on ITBPO. Large scale outsourcing has created a windfall both for Indian companies and the country. Demand for engineers is very high in India and the best students pursue degrees in engineering and Information Systems. In contrast, Information System disciplines in the US have very low demand as shown in Figure 2.

We should also look at Samsung, the largest conglomerate in South Korea. This company was rescued from bankruptcy by the Intel Corporation; today this company sports a market capitalization that is very close to that of Intel. Further, Samsung is the industry leader in new technologies such as LCDs, etc. The large number of talented employees in these Indian IT-BPO companies may soon challenge Microsoft, Oracle and Google.

The US government needs to review their reporting of trade statistics and include trading in services in their data collection. They should make sure that the universities continue to supply the labor pool with qualified and well trained engineers and software professionals in large quantities. The high-schools should refocus on Math and Science. This is essential for the continued prosperity of our nation.

\section{REFERENCES}

1. Accenture (2007). Form $10-\mathrm{K}$ for the Fiscal Year Ended December 31, 2007. Retrieved May 8, 2008 from http://www.sec.gov.

2. Amiti, M., Wei, S. (2004). Demystifying Outsourcing: The Numbers Do Not Support the Hype Over Job Losses. Finance and Development, December, 2004, 36-39.

3. Bardhan, A and Kroll, C (2003). The New Wave of Outsourcing Retrieved May 8, 2008 from http://repositories.cdlib.org/iber/fcreue/reports/1 $103 /$.
4. Bendor-Samuel P. (2000), Turning Lead Into Gold: The Demystification of Outsourcing, Utah, UT: Executive Excellence Publishing, 2000

5. Berelson, B. (1952). Content Analysis in Communication Research. Glencoe, Ill: Free Press.

6. Bhagwati Jagdeesh, Panagariya Arvind, and Srinivasan T.N. (2004). The Muddles over Outsourcing. Retrieved May 8, 2008 from http://www.columbia.edu/ ap2231/Policy\%20Pa pers/JEP_Outsourcing_Final.pdf.

7. Brudenall, P. (2005). Technology and Offshore Outsourcing Strategies. New York, NY: Palgrave Macmillan

8. Catherine Mann (2006), Accelerating the Globalization of America: The Role for Information Technology, Washington, D.C: Institute for International Economics.

9. Colvin, G. (2005). America Isn't Ready [Here's What To Do About It]: In the Relentless, Global, Tech-Driven, Cost-Cutting Struggle for Business. Fortune, July 25, 2005.

10. Computer Sciences (2007). Form 10-K for the Fiscal Year Ended December 31, 2007. Retrieved May 8, 2008 from http://www.sec.gov.

11. Dobbs Lou (2004), Exporting America Why Corporate Greed is Shipping American Jobs Overseas, New York, NY: Warner Business Books.

12. Economist (2004). Innovative India. April 3, 2004 p. 65-66.

13. EDS (2007). Form $10-\mathrm{K}$ for the Fiscal Year Ended December 31, 2007. Retrieved May 8, 2008 from http://www.sec.gov.

14. England, Christopher (2001), Outsourcing the American Dream, Bloomington, IN: Writer's Club Press.

15. Farrell, D, Laboissière, M, Pascal, R, Rosenfeld, J, de Segundo, C, Stürze, S. (2005). The Emerging Global Labor Market: Part I - The Demand for Offshore Talent in Services. San Francisco, CA: McKinsey Global Institute.

16. Farrell, D, Laboissière, M, Rosenfeld, J, Stürze, S, and Umezawa, F. (2005). The Emerging Global Labor Market: Part II - The Supply of Offshore Talent in Services. San Francisco, CA: McKinsey Global Institute.

17. Friedman, Thomas L. (2006) The World Is Flat: A Brief History of the Twenty-first Century. New York, NY. Farrar, Straus and Giroux

18. Georg Erber, Aida Sayed-Ahmed (2005) Offshore Outsourcing - A Global Shift in the Present IT Industry, Intereconomics, Volume 40, Number 2, March 2005, S. 100 - 112,

19. Hira, R and Hira,A (2005) Outsourcing America, What's Behind our national crisis and how we 
can reclaim American Jobs, New York, NY: American Management Association.

20. Holsti, O.R. (1969). Content Analysis for the Social Sciences and Humanities. Reading, MA: Addison-Wesley.

21. IBM (2006) Business Impact of Outsourcing Retrieved May 10, 2008 from http:/www03.ibm.com/services/ca/en/outsourcing_report.ht $\mathrm{ml}$.

22. IBM (2007). Form $10-\mathrm{K}$ for the Fiscal Year Ended December 31, 2007. Retrieved May 8, 2008 from http://www.sec.gov/

23. Indian Capital Market (2008) Retrieved May 8, 2008 from http://www.capitalmarket.com.

24. Infosys Technologies (2008) Retrieved May 8, 2008 from http://www.infosys.com.

25. Kassarjian, H. H. (1977), Content Analysis in Consumer Research, Journal of Consumer Research, 4 (June): 8-18.

26. Koch Christopher (2005). Innovation Ships Out, Retrieved May 8, 2008 from http://www.cio.com /archive/011505/outsourcing.html

27. Krippendorff, K. (1980). Content Analysis: An Introduction to Its Methodology. Newbury Park, CA: Sage.

28. Lohr, Steve (2004). An Elder Challenges Outsourcing's Orthodoxy? New York Times, 11 Sept. 2004

29. Mankiw, N \& Swagel, P. (2006). The Politics and Economics of Offshore Outsourcing, NBER Working Papers 12398, National Bureau of Economic Research, Inc.

30. Mark Kobayashi-Hillary. (2004). Outsourcing to India. The Offshore Advantage, New York, NY: Springer.

31. NASSCOM (2007). Strategic Review 2007, Nasscom, New Delhi, India

32. NASSCOM (2008). Strategic Review 2008, Nasscom, New Delhi, India.

33. National Academy of Public Administration. (2006). Off-Shoring: An Elusive Phenomenon, Report for the U.S. Congress and the Bureau of Economic Analysis: Washington.

34. Samuelson, Paul A (2004). Where Ricardo and Mill Rebut and Confirm Arguments of Mainstream Economists Supporting Globalization, Journal of Economic Perspectives, American Economic Association, vol. 18(3), pages 135-146.

35. Satyam Computer Services. (2008). Retrieved May 8, 2008 from http://www.satyam.com/

36. Securities and Exchange Commission (2008) Retrieved May 8, 2008 from http://www.sec.gov.

37. Software Engineering Institute (2008) Process Maturity Profile of the Software Community-
March 2008 Report, Software Engineering Institute, Carnegie Mellon, 2008.

38. Stemler, Steve (2001). An overview of content analysis. Practical Assessment, Research \& Evaluation, 7(17). Retrieved May 10, 2008 from http://PAREonline.net/getvn.asp?v=7\&n=17.

39. Tata Consultancy Services (2008) Retrieved May 8, 2008 from http://www.tcs.com.

40. Teubal, M. (2002). The Indian software industry from an Israeli perspective: A systems/ evolutionary and policy view. In India in the Global Software Industry: Innovation, Firm Strategies and Development, D'costa, A. and Sridharan, E. Eds. Palgrave Macmillan, New York, NY, 112-138.

41. The Huffington Post (2008) AT\&T CEO Says Hard To Find Skilled US Workers Retrieved May 8, 2008 from http://www.huffingtopost/

42. U.S. Census Bureau (2008). Foreign Trade Statistics Retrieved May 8, 2008 from http://www.census.gov/foreign-trade.

43. U.S. General Accounting Office (1996). Content Analysis: A Methodology for Structuring and Analyzing Written Material. GAO/PEMD10.3.1. Washington, D.C.

44. U.S. General Accounting Office (2005). U.S. and India Data on Offshoring Show Significant Differences. Washington, D.C: GAO/06-1006.

45. University of Alabama (2008) Retrieved May 8, 2008 from http://www.ua.edu.

46. Weber, R. P. (1990). Basic Content Analysis, 2nd ed. Newbury Park, CA.

47. Wipro Technologies Ltd. (2008) Retrieved May 8, 2008 from http://www.wipro.com.

48. Yahoo Finance (2008) Retrieved May 8, 2008 from http://finance.yahoo.com. 